\title{
Persepsi Orang Tua Siswa Kelas IV Terhadap Pentingnya Pembentukan Karakter Peduli Sosial
}

\author{
Deodora Adesita ${ }^{1}$, Rofian $^{2}$, Intan Rahmawati ${ }^{3}$ \\ 1,2,3 Jurusan Pendidikan Guru Sekolah Dasar, Fakultas IImu Pendidikan \\ Universitas PGRI Semarang, Indonesia \\ e-mail: deodora.adesota02@gmail.com, kotakomik.pian@gmail.com, \\ agoesq435@gmail.com
}

\begin{abstract}
Abstrak
Penelitian ini bertujuan untuk mengetahui Persepsi orang tua terhadap pembentukan karakter peduli sosial siswa, Penelitian ini merupakan jenis penelitian kualitatif dengan Subjek penelitian berjumlah 10 orang yang terdiri dari; 1 orang kepala sekolah, 1 orang guru kelas, 4 orang tua siswa, dan 4 orang siswa kelas IV di SD N Pagerdawung Kab, Kendal. Hasil penelitian berfokus kepada bagaimana persepsi orang tua terhadap pembentukan karakter peduli sosial siswa. Tehnik pengumpulan data yang digunakan adalah tehnik wawancara, observasi dan dokumentasi, dan hasil penelitian menerangkan bahwa adnya perbedaan perspsi orang tua terhadap pembentukn karakter peduli sosial siswa yang berdampak terhadap prestasi dan perilaku siswa yang bersangkutan.
\end{abstract}

Kata Kunci: Persepsi, Pembentukan Karakter, Peduli Sosial

\begin{abstract}
This study aimed to determine the perception of parents about the formation of social care characters of students, this research was qualitative research with 10 research subjects consist of; 1 school principal, 1 class teacher, 4 student parents, and 4 fourth grade students at SD N Pagerdawung Kab, Kendal. The results of the study focused on how parents 'perceptions of the formation of students' social care characters. Data collection techniques were interview techniques, observation and documentation, and the results of the study explained that there were differences in parents 'perspectives on the formation of students' social care characters that had an impact on student achievement and behavior.
\end{abstract}

Keywords: Perception, Character Building, Social Care 


\section{Pendahuluan}

Menurut Undang-Undang Sistem Pendidikan Nasional No.20 Tahun 2003 pasal 1 butir 1, pendidikan adalah: "usaha sadar dan terencana untuk mewujudkan suasana belajar dan proses pembelajaran agar peserta didik secara aktif mengembangkan potensi dirinya untuk memiliki kekuatan spiritual keagamaan, pengendalian diri, kepribadian, kecerdasaan, akhlak mulia, serta keterampilan yang diperlukan dirinya, masyarakat, bangsa dan Negara." Pendidikan nasional bertujuan: "untuk mengembangkan potensi peserta didik agar menjadi manusia yang beriman dan bertakwa kepada Tuhan Yang Maha Esa, berakhlak mulia, cakap, kreatif, mandiri, dan menjadi waarga Negara yang demokratis serta bertanggung jawab" (UU Sisdiknas No. 20 tahun 2003 pasal 3). Pengertian secara khusus, karakter adalah nilai-nilai yang khas baik (tahu nilai kebaikan, mau berbuat baik, nyata berkehidupan baik, dan berdamak baik terhadap lingkungan) yang terpatri dalam diri dan terwujud dalam perilaku. Dalam hubungannya dengan pendidikan, pendidikan karakter dapat dimaknai sebagai pendidikan nilai, pendidikan budi pekerti, pendidikan moral, pendidikan watak, yang bertujuan mengembangkan kemampuan siswa untuk memberikan keputusan baik buruk, memelihara kebaikan, mewujudkan dan menebar kebaikan dalam kehidupan sehari-hari dengan sepenuh hati (Ayu, 2017).

Pendidikan karakter adalah suatu sistem penamaan nilai-nilai karakter yang meliputi komponen pengetahuan, kesadaran atau kemauan, dan tindakan untuk melaksanakan nilainilai tersebut, baik terhadap Tuhan Yang Maha Esa, diri sendiri, sesama, lingkungan, maupun kebangsaan. Pengembangan karakter bangsa dapat dilakukan melalui perkembangan karakter individu seseorang.Akan tetapi, karena manusia hidup dalam lingkungan sosial dan budaya tertentu, maka perkembangan karakter individu seseorang hanya dapat dilakukan dalam lingkungan sosial dan budaya yang bersangkutan. Artinya, perkembangan budaya dan karakter dapat dilakukan dalam suatu proses pendidikan yang tidak melepaskan peserta didik dari lingkungan sosial,budaya masyarakat, dan budaya bangsa.Lingkungan sosial dan budaya bangsa adalah Pancasila, jadi pendidikan budaya dan karakter adalah mengembangkan nilainilai Pancasila pada diri peseta didik melalui pendidikan hati, otak, dan fisik. Pendidikan karakter atau pendidikan watak sejak awal munculnya pendidikan oleh para ahli dianggap sebagai suatu hal yang niscaya.John Sewey, misalnya, pada tahun 1916 yang mengatakan bahwa sudah merupakan hal yang lumrah dalam teori pendidikan bahwa pembentukan watak merupakan tujuan umum pengajaran dan pendidikan budi pekerti di sekolah (Omeri, 2015).

Menurut Mulyana (2005:167-168), persepsi merupakan proses internal yang memungkinkan kita memilih, mengorganisasikan dan menafsirkan rangsangan dari lingkungan kita dan proses tersebut yang mempengaruhi kita. Dari penjelasan Mulyana ini dapat disimpulkan bahwa persepsilah yang menentukan kita memilih pesan dan mengabaikan pesan yang lain. Menurut Walgito (2004: 124) persepsi merupakan suatu proses yang didahului oleh penginderaan. Penginderaan disini merupakan suatu proses diterima dari stimulus oleh individu melalui alat penerimanya. Namun proses tersebut tidak berhenti disitu saja, pada umumnya stimulus tersebut diteruskan oleh syaraf ke otak sebagai pusat susunan syaraf dan proses selanjutnya merupakan proses persepsi. Sedangkan menurut Sunaryo (2002: 94), perseps diri pada hakekatnya terjadi karena adanya rangsangan yang berasal dari dalam diri individu. Dalam hal ini yang menjadi obyek adalah dirinya sendiri.

Berdasarkan uraian diatas dapat disimpulkan bahwa faktor tentang fenomena sosial berdasarkan kognisi dan kategorisasi sistuasinya, kemudian mengorganisasikan dan menafsirkan stimulus yang selanjutnya menimbulkan tanggapan dan sikap serta perilaku yang terbentuk. Persepsi berkaitan dengan cara mendapatkan pengetahuan tentang obyek atau kejadian pada saat tertentu sehingga persepsi seseorang atau kelompok berbeda karena mempunyai sudut pandang yang berbeda. Persepsi meliputi penafsiran obyek, tanda dan orang dari pengalaman seseorang atau kelompok. Maka persepsi diri merupakan pandangan atau penilaian terhadap diri sendiri yang diperoleh dari hasil belajar atau pengalaman yang mempengaruhi individu tersebut untuk berinteraksi atau berperilaku dengan sekitarnya (Puspita, 2017).

Persepsi merupakan suatu proses yang didahului oleh pengindraan, yaitu merupakan proses yang berwujud diterimanya stimulus oleh individu melalui panca indra atau juga disebut proses sensoris. Banyak istilah persepsi yang dikemukakan oleh para ahli. Menurut Leavitt (1978) sebagaimana dikutip dalam Alex Sobur (2013 : 445) Persepsi dalam arti sempit adalah penglihatan, bagaimana cara seseorang melihat sesuatu; sedangkan dalam arti luas adalah pandangan atau pengertian, yaitu bagaimana seseorang memandang atau mengartikan sesuatu. Bimo Walgito (2007:87-88), mendefinisikan, Persepsi merupakan suatu proses yang 
didahului oleh proses pengindraan, yaitu merupakan proses diterimanya stimulus oleh individu melalui alat indra atau juga disebut proses sensoris. Persepsi orang tua terhadap pembentukan karakter peduli sosial bagi diri siswa menadi sangatlah penting bagi pertumbuhan dan perkembangan diri siswa tersebut. Hal ini tidak akan terlepas dari kemampuan orang tua dalam mempresepsikan nilai-nilai yang positif dalam pembentukan karakter peduli sosialnya kepada siswa.

Kepedulian merupakan tindakan atau perbuatan seseorang tentang ketertarikan pada orang lain ataupun pada situasi tertentu. Tindakan itu dapat berupa kasih sayang, perhatian atau empati. Orang-orang yang peduli tentang orang lain menunjukkan perasaan mereka melalui tindakan atau perbuatan mereka. Perbuatan atau tindakan ini apabila dilakukan secara terus menerus maka akan meningkatkan karakter kepedulian sosial anak.

Menurut Bapak Ari Wibowo, S.pd salah satu guru SD N Pagerdawung pada hari Sabtu, 13 Oktober 2018 mengenai karakter peduli sosial, beliau menyampaikan bahwa karakter peduli sosial sangat penting dan dirasa kurang berkembang dalam diri setiap siswa yang ada, dan menjadi hal yang sangat dikuatirkan oleh berbagai pihak.

Berdasarkan latar belakang tersebut di atas, maka ditemukanlah permasalahan pada persepsi orang tua terhadap pembentukan karakter peduli sosial siswa kela IV SD $\mathrm{N}$ Pagerdawung Kab. Kendal Jawa Tengah.

\section{Metode}

Penelitian ini menggunakan penelitian kualitatif yang menyajikan data menggunakan kata-kata.Hal ini sejalan dengan pendapat Lexy J. Moleong $(2005 ; 6)$ yang menyatakan bahwa penelitian kualitatif adalah penelitian yang bermaksud untuk memahami fenomena tentang apa yang dialami oleh subjek peneliti, misalnya perilaku, persepsi, motivasi, tindakan, secara holistik, dan dengan cara deskripsi dalam bentuk kata-kata dan bahasa,pada suatu kontekss khusus yang alamiah dan dengan memanfaatkan berbagai metode alamiah. Penelitian tentang persepsi orang tua siswa kelas IV terhadap pentingnya pembentukan karakter peduli sosial di SD Negeri Pagerdawung Kabupaten Kendal ini menggunakan pendekatan kualitatif yang hasilnya akan disajikan secara deskriptif. Penelitian ini bertujuan mendeskripsikan hasil temuannya apa adanya dan tidak menganalisis berdasarkan akurasi statistik. Oleh karena itu penelitian ini dapat dikatakan penelitian deskriptif kualitatif.

\section{Hasil dan Pembahasan}

Dalam paparan data dikemukakan informasi dari hasil pengolahan data dari apa yang diungkapkan informan (hasil dari wawancara), hasil pengolahan data dari apa yang diamati (hasil dari observasi), hasil pengolahan data dari apa yang dikutip dari dokumen (hasil dari mengutip/mengolah data yang bersumber dari dokumen).

Berdasarkan hasil wawancara dengan kepala sekolah, guru kelas, dan siswa serta observasi dan dokumentasi Penulis mencoba memaparkan tentang hal-hal sebagai berikut :

1) Bapak Hadi Waluyo, A.Ma.Pd, S.Pd. Kepala Sekolah SD N Pagerdawung.

Melalui wawancara yang dilakukan peneliti terhadap Kepala Sekolah pada tanggal 16 Mei 2019 dan melalui kegiatan observasi serta dokumentasi penelitian, maka dapat didapati keseriusan sikap dan kebijakan Kepala Sekolah yang sangat berpihak kepada perkembangan karakter siswa yang ada secara keseluruhan. Seperti yang terungkap dalam salah satu petikan wawancara kepada Kepala Sekolah SD N Pagerdawung.

Pertanyaan; Apa Yang Menjadi Program Pihak Sekolah Dalam Menyikapi Perkembangan Karakter Siswa Di Sekolah? Jawab; "Telah Banyak Kegiatan-kegiatan Dan Program-program Sekolah, Baik Dlam Bidang Akademik Maupun Non Akademik Yang Mengarah Serta Membantu Perkembangan Karakter Sekolah, Seperti Kegiatan Ekstrakulikuler dan Pemberian Bimbingan Karakter Melalui Mata Pelajaran Yang Diberikan DI Dalam Kelas".

Pertanyaan; Apakah Sekolah Menyediakan Alat Atau Pasilitas Dalam Menunjang Perkembangan Pendidikan Karakter Siswa? Jawab; "Fasilitas dan alat bantu dalam menunjang perkembangan karakter siswa di sekolah cukup memadai, sekolah setiap tahun tetap mengalokasikan dana bantuan yang didapat sekolah untuk terus melengkapi kebutuhan yang dimaksud".

Dari hasil observasi dan dokumentasi, peneliti mendaapatkan banyak informasi tentang kegiatan-kegiatan dan program-program sekolah baik yang bersifat akademik maupun non akademik yang memang jelas berkaitan dengan pendidikan karakter siswa yang ada, dan 
sebagian yang dimaksud telah dituliskan peneliti pada bsub gabian program dan implemntasi pendidikan karakter di sekolah.

2) Bapak Ari Wibowo, S.Pd. Guru Kelas IV SD N Pagerdawung,

Melalui hasil wawancara didapat pandangan Pak Ari terhadap pembentukan karakter peduli sosial siswa yang di didiknya menjadi suatu bagian yang sangat penting dalam proses belajar mengajar di sekolah. Menurutnya, peran serta orang tua siswa tidak dapat dilepaskan dalam pembentukan karakter peduli sosial siswa, sehingga apa yang dilakukan Pak Ari dalam upaya tersebut selalu memiliki komunikasi yang baik dengan orang tua siswa yang ada.

Sementara hasil observasi dan dokumentasi dapat diungkapkan beberapa hal sebagai berikut tentang sosok Pak Ari sebagai guru kelas IV di SD N Pagerdawung. Dalam kegiatan belajar mengajar di dalam kelas, Pak Ari selalu berusaha menyatakan perkataan-perkataan motifasi dan bijak kepada siswa dan sangat sering Beliau juga mengadakan kegiatan permainanpermainan ringan yang dapat membantu siswa dalam memahami pembelajaran karakter yang dimaksud. Pak Ari menjadi salah satu guru yang sangat disukai setiap murid, sifat pendidik dan pembimbing dalam dirinya sangat dominan dan terungkap. Sikap ramah dan tutur kata yang baik dalam memberikan pembelajaran di kelas menjadi salah satu kelebihan yang dimiliki Pak Ari dan patut dibanggakan.

3) Bapak Sawargiyono. Orang Tua Siswa.

Pak Yono sangat perduli dengan pembentukan karakter peduli sosial siswa. Banyak harapan dan keinginan yang baik dari dalam diri SG melalui pembentukan karakter peduli sosial siswa, baik di sekolah maupun di lingkungan rumah. Beliau tidak pernah segan untuk bertanya kepada pihak sekolah tentang perkembangan akademik dan non akademik siswa di sekolah, hal tersebut dilakukan sebagai tolak ukur beliau dalam menerapkan disiplin kepada siswa di lingkungan rumah. Hal ini dapat terungkap dari salah satu pertanyaan wawancara yang diajukan kepada Pak Yono.

Pertanyaan; Bagaimana Pandangan Bapak/lbu Tentang Sikap Peduli Sosial Siswa Di Rumah Dan Sekolah? Jawab; "Pembentukan Karakter Peduli siswa itu sangat penting karena merupakan tahap awal/dasar untuk mencapai cita-cita masa depa siswa itu sendiri".

4) Bapak Abdul Wakhid. Orang Tua Siswa.

Dalam wawancara yang dilakukan kepada Pak Wahid, Peneliti menemukan jawaban yang penting tentang bagaimana presepsi Pak Wahid terhadap perkembangan karakter peduli sosial anaknya. Pertanyaan; Apa Makna Persepsi Orang Tua Terhadap Pembentukan Karakter Peduli Sosial Siswa? Jawab; "persepsi Orang Tua terhadap Perkembangan Karakter Peduli Sosisal siswa itu sangat penting, karena persepsi yang tepat dan benar akan sangat membantu siswa memperoleh bekal hidup di masa depan dalam upaya mencari pekerjaan dan menjalani kehidupannya dengan lebih mudah"

Persepsi Pak Wahid terhadap perkembangan karakter peduli sosial siswa telah membentuk situasi kehidupan yang positif dalam lingkungan keluarga mereka.

5) Ibu Siti Nur Arifah. Orang Tua Siswa.

Saat dilakukan wawancara dan observasi, Peneliti tidak menemukan jawaban-jawaban serta hasil pengamatan yang memiliki arti bahwa lbu Siti adalah sosok Orang Tua yang memahami dan sangat perduli terhadap perkembangan anak. Ada kesan bahwa lbu Siti lebih memilih sikap membiarkan masalah pendidikan dan perkembangan karakter anaknya menjadi tugas pihak sekolah. Di lingkungan rumah, Beliau juga membiarkan kedua putrinya tumbuh dan berkembang dalam pengawasan pembantu rumah tangga.

Perkembangan alat komunikasi yang sangat pesat menjadi konsumsi utama kedua anaknya. Sebagian besar waktu kosong yang ada, mereka habiskan hanya untuk bermain games dan melihat hand phone serta media televisi. Hal ini tidak jauh berbeda dengan sikap hidup Ibu Siti sendiri, alat komunikasi dan informasi telah menjadi bagian yang paling penting dalam kehidupannya. Keadaan inilah yang menjadi salah satu sebab adanya kesenjangan hubungan antara lbu Siti dengan kedua anaknya.

6) Ibu Jaryati. Orang Tua Siswa.

Dalam kegiatan wawancara yang dilakukan, telah terungkap bahwa lbu Yati sangat perduli dan menganggap sangat penting dengan apa yang dimaksud perkembangan karakter peduli sosial siswa. Salah satu butir pertanyaan dan jawaban yang dimaksud adalah, Pertanyaan; Bagaimana Pandangan Bapak/lbu Tentang Sikap Peduli Sosial Siswa Di Rumah Dan Sekolah? Jawab; "Pembentukan karakter itu sangat penting, termasuk pembentukan karakter peduli sosial siswa, karena hal tersebut dapat menumbuhkan kepribadiian yang baik dalam diri siswa itu sendiri".

Melalui pengamatan yang dilakukan Peneliti, didapati sikap hidup sehari-hari yang sangat 
positif dari diri lbu Yati. la selalu bersedia mendampingi setiap kegiatan siswa di sekolah maupun di lingkungan rumah, sehingga setiap informasi tentang siswa mampu ia ketahui dan perhatikn dengan lebih baik. Ibu Yati juga memiliki pengaturan waktu yang baik bagi setiap kegiatan siswa di rumah dan di sekolah. Pembagian waktu yang tepat antara kegiatan rutin siswa dengn kegiatan bermain siswa diterapkannya dalam mengasuh dan mendidik siswa di lingkungan rumah. Beliau tidak akan pernah membiarkan siswa di rumah unuk bermain apapun (terutama games online) melebihi batas waktu yang wajar.

7) Jesi Amanda. Siswi Kelas IV SD N Pagerduwung.

Dalam kehidupan sosial di sekolah, Jesi merupakan anak yang sangat terbuka bagi teman-teman lainnya, sehingga la mampu memiliki banyak teman yang sangat dekat dengan dirinya. Komunikasi dengan guru dan teman-teman di sekolah mampu dilakukannya dengan baik dan lancar, serta memiliki rasa peduli yang tinggi antar sesama. Hal inilah yang membuat dirinya menjadi sosok pribadi yang sangat menyenangkan banyak pihak.

Dengan kemampuan berkomunikasi yang cukup baik serta prilaku yang supel, telah mampu menjadikan Jesi bertumbuh menjadi sosok pribadi yang penuh dengan bakat-bakat alami yang mudah berekmbang.

8) Manda Aprita Sari. Siswi Kelas IV SD N Pagerduwung.

Meski sering nampak terlihat malu-malu dalam sikap dan perilakunya, Manda tetap memiliki beberapa teman baik dan sangat dekat di kelasnya. la mampu menciptakan rasa aman dan nyaman bagi teman-temannya, tidak jarang muncul ide-ide kreatif dalam bentuk permainan yang diciptakannya untuk mengajak temannya bermain. Walau terkesan ekslusif hanya dengan beberapa teman namun dapat dikatakan bahwa Manda adalah sosok siswi yang memiliki kepedulian sosial tinggi.

Melalui pengamatan yang dilakukan di sekolah maupun di lingkungan rumah, terlihat jelas bahwa Manda memiliki rasa tanggung jawab diri yang kuat dalam melakukan serta mengerjakan setiap tugas-tugas dalam kehidupannya. la telah mampu membedakan antara tanggung jawab dirinya dengan waktunya disaat-saat ia harus bermain bersama dengan temanteman sebayanya.

9) Adinda Aulia Putri. Siswi Kelas IV SD N Pagerduwung.

Kedua orang tuanya sangat sibuk dengan pekerjaannya masing-masing. Ayahnya seorang buruh pabrik dan ibunya membuka usaha kuliner online yang sering keluar rumah untuk mengantarkan pesanan konsumen. Tidak jarang Adinda berperan sebagai pengasuh adiknya di rumah, dan sering pula la membantu pekerjaan ibunya dalam memproduksi jenis makanan yang ditawarkan.

Keadaan keluarga di rumah ternyata berdampak kepada sikap dan prilaku Adinda di sekolah, Dirinya telah menjadi pribadi yang sulit berteman dengan siapapun juga. Di sekolah la lebih suka menyendiri, bahkan pada saat waktu istirahat sekolah la juga jarang terlihat bermain atau berkumpul dengan teman-teman sekolahnya, ada kesan bahwa Adinda tidak terlalu perduli dengan lingkungan sekitar dan mudah marah dengan keadaan yang tidak disukainya serta suka bersikap kasar secara verbal dan non verbal kepada teman-temannya disekolah.

10) Elma Septyana. Siswi Kelas IV SD N Pagerduwung.

Elma memiliki banyak prestasi di bidang akademik dan non akademik. Sejak kelas Satu Sekolah Dasar la selalu meraih peringkat pertama untuk nilai raportnya, dan dalam bidang non akademik Elma mengikuti kegiatan-kegiatan olah raga (Atletik, Renang dan Badminton) juga kegiatan kesenian (Menari dan Bernyanyi), banyak perlombaan-perlombaan pada kedua bidang tersebut yang diikutinya, dan sering pula la meraih hasil yang memuaskan dari setiap lomba. Kedua orang tuanya memiliki pandangan bahwa perkembangan karakter peduli sosial siswa adalah sesuatu yang sangat penting, dan melalui kegiatan-kegiatan yang positif maka hal tersebut lebih mudah dicapainya.

Kedisiplinan dan hubungan yang baik yang selalu diterapkan oleh kedua orang tuanya di lingkungan rumah telah membuat Elma menjadi anak yang memiliki pertumbuhan serta perkembangan yang sangat baik. Bahkan Elma mampu mengatur kegiatan kehidupan dirinya sehari-hari secara mandiri, meski terus ada dalam pengawasan dan bimbingan kedua orant tuanya.

Berdasarkan hasil observasi dan wawancara pada subyek penelitian diperoleh gambaran mengenai persepsi orang tua siswa kelas IV terhadap pentingnya pembentukan karakter peduli sosial di SD N Pagerdawung Kabupaten Kendal. Dapat terlihat adanya pandangan dan pemahaman serta sikap yang berbeda diantara orang tua terhadap perkembangan karakter peduli sosial siswa masing-masing. Beberapa orang tua siswa merasa bahwa pembentukan karakter peduli sosial siswa merupakan hal yang sangat penting terjadi pada diri anak, dan 
perasaan tersebut menjadi pendorong atau motif utama dari orang tua untuk bersikap arif dalam memperlakukan serta memperhatikan pertumbuhan juga perkembangan diri anaknya. Di lain sisi ada juga orang tua yang kurang memahami arti dan pentingnya pembentukan karakter peduli sosial anaknya sendiri.

Perbedaan persepsi orang tua terhadap pembentukan karakter peduli sosial siswa dapat menjadi dasar atas tumbuh kembangnya siswa dalam mengikuti proses belajar mengajar di sekolah dan atas perubahan sikap serta prilaku siswa dalam lingkungan kehidupannya. Meski pembentukan karakter peduli sosial siswa yang terjadi dalam tingkatan Sekolah Dasar masih pada tataran sederhana namun persepsi masing-masing orang tua tersebut sangatlah menjadi penting bagi keberhasilan proses pendidikan siswa itu sendiri.

Dengan ditemukannya perbedaan persepsi orang tua terhadap perkembangan karakter peduli sosial siswa dalam penelitian ini, telah membuka dan didapati juga fakta-fakta baru tentang pengetahuan tumbuh kembang diri siswa pada tingkat Sekolah Dasar yang harus menjadi perhatian serta membentuk komitmen orang tua itu sendiri guna membantu siswa memiliki proses tumbuh kembang dalam dirinya menjadi lebih baik.

Kemajuan jaman dan perkembangan dunia pendidikan yang begitu pesat tidak dapat diabaikan oleh orang tua, karena sekecil apapun peran serta orang tua dalam dunia pendidikan anaknya akan memberikan dampak yang positif bagi perkembangan anak itu sendiri. Seperti halnya dengan persepsi orang tua terhadap pembentukan karakter peduli sosial siswa yang jelas sangat dibutuhkan. Hal ini menjadi sangat penting bagi orang tua dalam membantu siswa mengembangkan potensi dirinya serta dapat menjadi modal dasar untuk siswa dalam mencapai segala cita-cita dan harapan-harapan kehidupannya, sebagaimana fungsi dan tujuan dari pembentukan karakter itu sendiri.

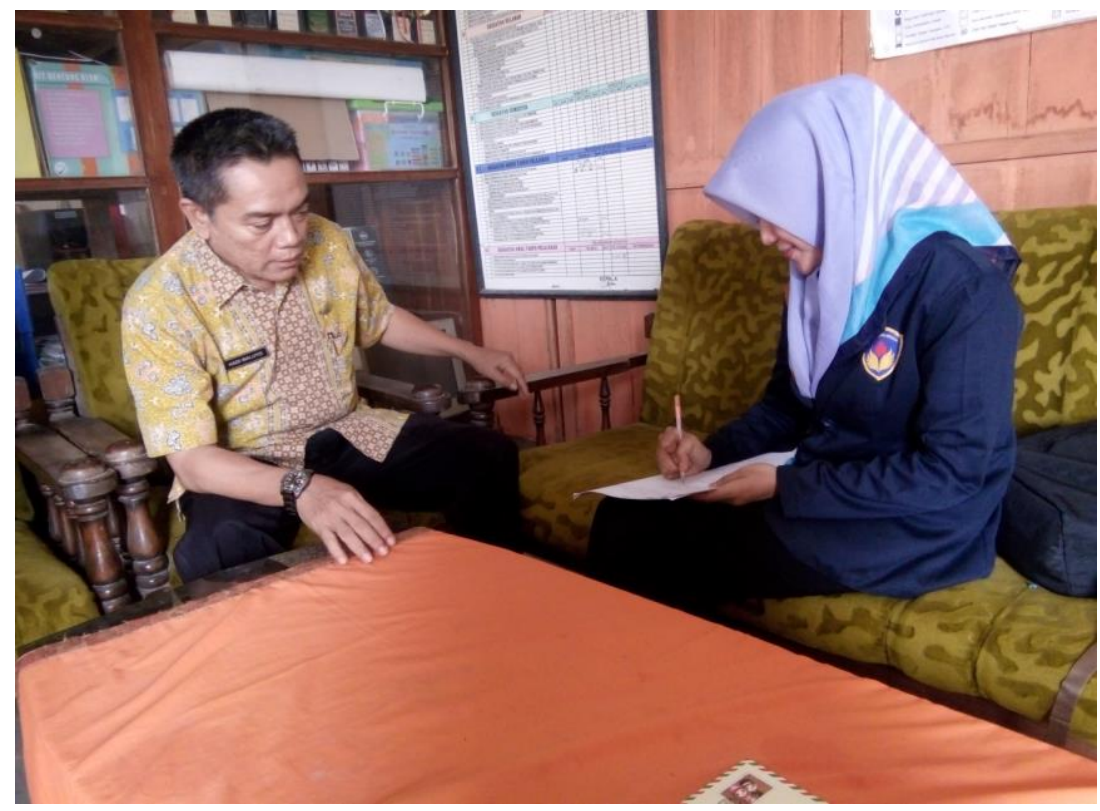

Gambar 1. Wawancara dengan kepala sekolah SDNPagerdawung

\section{Simpulan dan Saran}

Berdasarkan hasil penelitian dan penjelasan yang telah diuraikan dalam penelitian ini, maka peneliti dapat menyimpulkan hal-hal sebagai berikut :

Adanya perbedaan persepsi orang tua terhadap perkembangan karakter peduli sosial siswa kelas IV di SD N Pagerdawung Kab. Kendal Jawa Tengah yang berdampak terhadap prestasi serta perilaku siswa dalam kehidupannya. Beberapa orang tua siswa sangat merasa penting mengetahui dan mengharapkan adanya perkembangan karakter peduli sosial pada diri anaknya, sementara orang tua siswa lainnya hanya bersikap acuh terhadap hal tersebut.

Berdasarkan kesimpulan di atas, penulis mencoba membuat saran-saran yang mungkin dapat dilakukan oleh berbagai pihak yang merasa memiliki kepentingan terhadap penelitian yang telah dilakukan ini. Adapun saran-saran yang dapat dibuat penulis adalah sebagai berikut

Kepala Sekolah SD N Pagerdawung Kab. Kendal lebih lagi meningkatkan programprogram dan kegiatan-kegiatan sekolah yang melibatkan peran serta orang tua siswa. Guru 
IVCEJ, Vol 2 No 2, Tahun 2019

p-ISSN: 2615-4684 e-ISSN: 2615-6938

Kelas IV SD N Pagerdawung Kab. Kendal rela memberikan waktu luangnya untuk mengawasi gerak-gerik siswanya dalam lingkup permainan dan pertemanan antar sesama, serta peran aktif untuk menjadi motifator bagi siswa dan orang tua dalam program perkembangan karakter peduli sosial siswa juga diperlukan. Bagi orang tua siswa kelas IV SD N Pagerdawung Kab. Kendal membentuk komunitas antar orang tua yang bertujuan untuk berbagi informasi tentang perkembangan sikap dan prilaku anak baik di sekolah maupun di rumah, serta lebih berperan aktif dalam mengawasi dan memperhatikan kegiatan-kegiatan siswa di sekolah maupun di luar sekolah dan rela memberi waktu khusunya untuk membimbing siswa dalam mengembangkan karakter juga potensi dirinya. Untuk itu, diperlukan pertemuan rutin antara pihak sekolah dengan orang tua untuk membahas dan mengontrol masalah perkembangan karakter siswa dan perencanaan program-program dan kegiatan-kegiatan yang disusun dan ditetapkan bersama pihak sekolah dengan orang tua siswa di SD N Pagerdawung Kab. Kendal.

\section{Daftar Pustaka}

Alma, Buchari. 2015. Pembelajaran Studi Sosial. Bandung: Alfabeta

Ayu, Nanda . 2017. Pendidikan Karakter Sebagai Pilar Pembentukan Karakter Bangsa . Jurnal Fakultas IImu Sosial Universitas Negeri Medan Tahun 2017 Vol. 1 No. 1 2017, Hal. 348352

Creswell W. John. 2010. Research Design Pendidikan Kualitatif, Kualitatif, dan Mixed ). Yogyakarta : Pustaka Pelajar

Djamal. 2016. Fenomena Kekerasan disekolah . Yogyakarta: Pustaka Pelajar

Helmawati. 2014. Pendidikan Keluarga. Bandung: PT Remaja Rosdakarya

Herdiansyah, Haris. 2014. Metodelogi Penelitian Kualitatif untuk ilmu-ilmu Sosial. Jakarta:Salemba Humanika.

Jafar, Nurhaedar. 2016.Pertumbuhan dan Perkembangan Anak Sekolah. Makalah ilmiah.Makasar:Universitas Hasanudin Makasar. http://repository.unhas.ac.id/bitstream/handle/123456789/20887/MAKALAH\%20PERTUM BUHAN\%20ANAK\%SEKOLAH\%20fix.docx?sequence=1 diakses tanggal 1 Mei 2019.

Meleong, Lexy J. 2005. Metodelogi Penelitian Kualitatif. Bandung : PT Remaja Rosdakarya

Muslich, masnur.2011. Pendidikan karakakter menjawab tantangan krisis multidimensional. Jakarta : PT BumiAksara

Omeri, Nopan. 2015 . Pentingnya Pendidikan Karakter Dalam Dunia Pendidika .Jurnal Manajer Pendidikan, Volume 9, Nomor 3, Juli 2015, hlm. 464-468

Puspita, Tantri . 2017. Proses Persepsi Diri Mahasiswi Dalam Berbusana Muslimah . Jurnal Pemikiran Islam ISSN 2407-1706 ISSN 0853-1161 Edisi Desember 2017 Vol. 41 No. 2

Setiadi, Elly M.dkk 2007. IImu Sosial dan Budaya Dasar. Jakarta:Kencana

Rofian. 2016. PENERAPAN METODE PEMBELAJARAN DEMOSTRASI PADA PENDIDIKAN SENI RUPA DI SEKOLAH DASARhttps://ejournal.undiksha.ac.id/index.php/Ml/article/view/16494

Siregar,Nina Siti Salmaniah.2013."Persepsi Orang tua Terhadap Pentingnya Pendidikan Bagi Anak". http://ojs.uma.ac.id/index.php/jppuma diakses pada tanggal 09 April 2019.

Sobur,Alex.2013.Psikologi Umum dalam Lintas Sejarah.Bandung:Pustaka Setia

Sugiyono. 2016. Metode Penelitian Pendidikan: Pendekatan Kuantitatif, Kualitatif, dan $R$ and D. Bandung : Alfabeta 
IVCEJ, Vol 2 No 2, Tahun 2019

p-ISSN: 2615-4684 e-ISSN: 2615-6938

Walgito,Bimo.2007. Pengantar Psikologi Umum. Yogyakarta:Andi

Wikipedia.id.2019. https://id.m.wikipedia.org/wiki/sekolah_dasar. Diunduh !5 April 2019

Wulandari,ayu.2017."Pengaruh Persepsi Orang Tua Tentang Pendidikan Formal dan Lingkungan Tempat Tinggal Terhadap Pekerjaan Anak di Kelurahan Pidada Kecamatan Panjang Kota Bandar Lampung".Skripsi.Bandar Lampung. Universitas Bandar Lampung. http://digilib.unila.ac.id/26105/10/SKRIPSI\%20TANPA\%20BAB\%20PEMBAHASAN.pdf diakses tanggal $15 \mathrm{~A}$ [ril 2019

Wulandari,ayu.2017."Pengaruh Persepsi Orang Tua Tentang Pendidikan Formal dan Lingkungan Tempat Tinggal Terhadap Pekerjaan Anak". http://jurnal.fkip.unila.ac.id/index.php/JKD/article/view/12373 diakses pada tanggal 14 Mei 2019

Zubaedi.2011. Desain Pendidikan Karakter.Jakarta:Kencana 